\title{
Instrumentum vocale, mallams e alufás: o paradoxo islâmico da erudição na diáspora africana no Atlântico*
}

\author{
José Cairus \\ Em geral vão quase todos sabendo ler e escrever em caracteres \\ desconhecidos, que se assemelham ao árabe, usado entre os \\ Ussás, que figurão terem hoje combinado com os Nagôs. \\ [Relatório do chefe de polícia, \\ Francisco Gonçalves Martins, em 1835]
}

\section{Introdução}

O estudo da diáspora africana no Brasil nas últimas décadas, em consonância com os estudos deste tópico principalmente no mundo acadêmico anglo-saxão, exige dos historiadores além de dotes interdisciplinares, um grau crescente de especialização e erudição. A descoberta, ou melhor, a redescoberta dos africanos e a percepção da pluralidade cultura desses indivíduos reflete-se em uma produção acadêmica erudita e eclética. Aberta a "Caixa de Pandora" da escravidão percebeu-se mais: que não bastava de-

\footnotetext{
* Este artigo é baseado em um dos capítulos da minha dissertação de mestrado apresentada ao Programa de Pós-graduação em História Social da UFRJ (CAIRUS, José A. T. Jihad, cativeiro e redenção: escravidão, resistência e irmandade, Sudão Central e Bahia (1835). Dissertação de mestrado, Rio de Janeiro, 2002). Agradeço aos professores Arno Wehling e José Murilo de Carvalho as contribuiçôes sugeridas durante a defesa e ao meu orientador professor Manolo G. Florentino. Gostaria de fazer uma menção especial à erudição e à generosidade do embaixador Alberto da Costa e Silva, ao meu orientador no doutorado, em York, professor Paul E. Lovejoy e ao Harriet Tubman Resource Center on Africa Diaspora, pela oportunidade de estar fazendo parte de uma experiência rara em estudos africanos. Este artigo foi em parte reescrito e finalizado em Lisboa, graças a bolsa concedida pelo Serviço Internacional da Fundação Calouste Gulbenkian.
} 
tectar-se estruturas culturais monolíticas e exóticas trazidas pelos africanos na sua saga transatlântica mas outrossim, dentro de uma perspectiva bem mais alargada, entender as mudanças radicais ou sutis operadas em solo africano e transportada nos negreiros. Mudanças que ocorreram muitas vezes na hinterlândia africana, e portanto, longe de qualquer interferência ou influência européia, então quando muito, encerrados em feitoras e fortalezas ao longa da costa africana e tendo que contar com boa vontade dos régulos locais. Nas rotas de comércio, quer fosse transariano ou subsariano, cruzando a zona de transição do Sael e penetrando na floresta tropical, afluíam comerciantes, clérigos e revolução, transportando mercadorias (incluindo seres humanos), religião e idéias respectivamente.

Grandes espaços geográficos não apenas separam, mas também unem, de acordo com seus caprichos naturais, por uma perspectiva que poderíamos definir como braudeliana. Foi assim no Mediterrâneo, no Sara (chamado não por acaso de "Mediterrâneo sariano" por Vitorino Magalhães Godinho), no Índico e no Atlântico, entre outros. Pois é essa a alma do presente artigo, oferecer aos leitores a percepção de uma África e conseqüentemente uma América, conectada a mundos, ideologias e com legislação próprias e diversas das existentes no Ocidente. As análises aqui apresentadas foram incorporadas a partir de um viés que transcende teorias historiográficas estabelecidas, e insere o tópico em um mundo consideravelmente maior, o Dar-al-Islam, exilado, recriado e transformado, neste caso, em terras brasileiras. ${ }^{1}$

Metodologicamente produziu-se esse artigo a partir de fontes secundarias especializadas e de documentação primária, que por sinal, repousa placidamente em arquivos brasileiros.

\section{As fontes e o surgimento de uma jurisprudência islâmica}

O suprimento de escravos originários do golfo de Benin mudou dramaticamente a partir do século XVIII e no decorrer do século XIX. Enquanto o império de Oió foi o principal fornecedor de escravos, as etnias nupe, borgu, hauçá e outras do grupo lingüístico ewe foram maciçamente enviadas à Costa dos Escravos. No século XIX, com a destruição de Oió, inicia-se o fluxo contínuo de povos falantes do iorubá para os entrepostos 
escravos no golfo de Benin. No entanto, o surgimento do Califado de Socoto, no Sudão Central, criou um trânsito secundário de escravos hauçás. No início do século XIX, surgem pelo menos dois fluxos demográficos distintos no tráfico da África Ocidental. Um dos fluxos buscava escravos na hinterlândia e os transportava para a costa, outro fez uma rota do litoral, com escravos do sexo masculino, mulheres e crianças, no sentido contrário.

Raramente, segundo Lovejoy, na história da escravidão nas Américas, foi possível correlacionar as trajetórias de origem dos escravos na África com as sociedades escravistas em que viveram na Américas. No caso do golfo de Benin e da Bahia, no século XIX, foi possível conectar origens, inserção no tráfico e o estabelecimento desses indivíduos do outro lado do Atlântico. A cultura, ocupação e práticas religiosas são razoavelmente conhecidas e quando a origem desses grupos da população escrava baiana é analisada sob esses aspectos, as razóes da revolta de 1835 e a capacidade de resistência organizada contra a cultura dominante, especificamente na Bahia, tornamse mais claras e, ao contrário do que tem sido estabelecido, perfeitamente viáveis dentro de uma perspectiva africanista. ${ }^{2}$

Pode-se dizer que existe um consenso sobre a presença de escravos em diversas sociedades através do tempos, e de legislações específicas que regulavam essas relaçóes. Portanto, na primeira parte do artigo o estudo de caso da jurisprudência islâmica maliquita sobre a escravidão pode esclarecer estruturas sociais e jurídicas preexistentes para certos grupos de africanos escravizados enviados para o Brasil

A partir da percepção da existência de uma legislação diversa pode-se especular, em terreno mais concreto, o impacto dessas diferenças sobre os africanos originários de sociedades sob a tutela de um corpo de leis consideravelmente sofisticada.

A escassez de fontes secundárias para os dois primeiros séculos da era islâmica pode ser explicada pela falta de documentos que expliquem as mudanças substanciais na jurisprudência sobre a escravidão ocorridas entre o Corão e as primeiras fontes legais. ${ }^{3}$ Esse hiato abrange um período de 135 anos entre 632 e 767. Antes disso o Corão e as fontes históricas podem ser usados para avaliar as condições primitivas dos escravos no Islã. Para o período posterior a 767, pode ser utilizado o corpo jurídico maliquita a partir das obras al-Muktasar al-kabir e Muwatta. 
Devido à falta de documentação independente para essa época, algumas questôes importantes levantadas sobre a historicidade das fontes literárias precisam ser enfocadas. A reconstrução da jurisprudência islâmica sobre a escravidão e sua prática no período da Revelação corânica baseiase, segundo Brockopp, no terreno das delicadas fontes literárias tradicionais do Corão e nos hadiths com a biografia do Profeta. No seu estudo ele utilizou a versão padrão egípcia do Corão como fonte de informação sobre o tratamento de escravos antes de $632 .{ }^{4}$

O estudo das primeiras leis revela uma extraordinária disposição de debater as implicações legais dos versículos corânicos e a tendência de se interpretar os hadiths para preestabelecer pontos de vista legal. Outra questão é a admissão clara da escravidão encontrada no Corão (assim como em outros textos religiosos) e a inexistência de escravos nas sociedades islâmicas atuais. A escravidão, profundamente incorporada à sociedade islâmica no passado, não faz parte da agenda político-social nem dos mais conservadores dos estados islâmicos modernos. No final do século XIX, os ideais de justiça e igualdade entre os crentes prevaleceram sobre a opressiva instituição da escravidão. ${ }^{5}$ A decisão de se modificar um aspecto da lei islâmica nunca havia sido objeto de questionamento. Mudanças de teorias morais tão profundamente arraigadas implicam questôes incômodas que resistem ao desmantelamento, como no caso de instituições opressivas.

A história da escravidão sobre o tratamento dos escravos no texto corânico e no tempo do Profeta pode ser reconstruída de forma confiável devido às informações biográficas preservadas pelos muçulmanos de todo e qualquer individuo próximo ao Profeta. A escravidão doméstica nos séculos posteriores é menos conhecida. Entretanto, a vida de escravos palacianos, soldados e escravas treinadas como poetisas, tem sido objeto de estudos recentes. ${ }^{6}$

No tempo da elaboração da lei maliquita, os juristas islâmicos já haviam desenvolvido uma estrutura sofisticada e um vocabulário próprio sobre a jurisprudência escrava. Todos os primeiros textos legais compartilhavam algumas categorizações básicas. Por exemplo, os deveres religiosos (ibadat) eram tratados, primeiramente, seguindo-se a herança, o casamento e o divórcio. ${ }^{7}$ Os juristas reservaram cerca de cinco capítulos particularmente para a emancipação de escravos (itq), a relação do liberto com o cliente de 
seu ex-senhor (wala), o escravo a quem era prometido a manumissão após a morte do senhor (mudabbar), o mukatab (escravo com contrato de emancipação) e umm walad (escrava que dava a luz à criança do seu senhor). ${ }^{8} \mathrm{O}$ ponto significativo é a ênfase dada pelos juristas às questôes concernentes à emancipação, em detrimento do tratamento devido aos escravos e os seus deveres. A despeito das limitações das fontes, o material conhecido é suficiente para uma análise ampla de questôes específicas. Para a primeira categoria de emancipação, Malik ibn Anas, baseado na sunnah, proibiu manumissões que resultassem em liberdade parcial. Por exemplo, a situação em que apenas um detentor da parte do escravo concedesse a emancipação. Se esse sócio desejasse emancipar sua parte, teria que estar preparado para comprar a parte do seu outro sócio. ${ }^{9}$ No caso de herança, Malik adotou o princípio básico de que o falecido poderia apenas legar um terço de sua propriedade. Os dois terços restantes deveriam ser divididos entre os herdeiros, de acordo com as leis corânicas sobre herança. Portanto, se um senhor fixasse em testamento a emancipação de escravos com valor correspondente acima do terço permitido, muito teria que ser discutido sobre quem realmente poderia ser emancipado. Nessa situação a emancipação parcial era possível. Finalmente Maliki ibn Anas vetava expressamente a emancipação que estipulasse qualquer tipo de serviço do escravo liberto. ${ }^{10}$

A jurisprudência maliquita tratou também de casos específicos de emancipação. No caso do senhor que ferisse seu escravo, ele poderia ser forçado a vendê-lo. ${ }^{11}$ Era proibido ao senhor emancipar escravos quando a emancipação resultasse em perigo para o emancipado. ${ }^{12}$ Quando o senhor fosse obrigado a libertar um escravo como punição de algum crime, o senhor era compelido a emancipar escravos que lhe causassem prejuízo real. ${ }^{13}$ Ainda sobre essa questão, o indivíduo que precisasse comprar um escravo para libertá-lo como punição de um crime cometido não poderia mencionar o fato ao vendedor de escravos. Presumivelmente essa prática visava impedir que o dono anterior pudesse reduzir o preço original como ato de caridade e, portanto, beneficiar o punido. É preciso lembrar que as regulamentaçôes em questão foram concebidas para os senhores, não obstante muitas delas terem contribuído para melhorar a situação dos escravos categorizados pela lei.

As questôes envolvendo vínculos de clientela na jurisprudência maliquita derivam-se da posição do escravo como parte da estrutura familiar. É significativo que Maliki ibn Anas não tenha discutido os benefícios 
das relações de clientela, mas sim essas relações em diferentes situações de disputa. ${ }^{14}$ A sofisticação da lei maliquita pode ser constatada pela sua especificidade, como por, exemplo, no caso da escrava grávida durante o processo de emancipação, e cujo marido continuava a ser escravo. ${ }^{15} \mathrm{Na}$ mesma parte do código maliquita, trata da questão de quando o status do escravo bloqueia a sucessão da herança. Em alguns casos pode ser bloqueado, por exemplo, no de uma criança nascida de um relacionamento de uma mulher livre e um escravo que falece posteriormente. Nestas condições, a herança da criança passa para a linha sucessória materna por linhagem agnata. ${ }^{16}$ No entanto, se o pai, mesmo na condição de escravo, possuir um avô livre, este passa a ter direito sobre sua herança. Finalmente nessas questôes envolvendo os vínculos de clientela, o código maliquita estabeleceu que essa relação não é objeto de negociação e, portanto, não pode ser alienada do seu detentor sob qualquer alegação. ${ }^{17}$

A contribuição corânica pode ser traduzida na sua ênfase em contextualizar o escravo na sociedade e na responsabilidade desta sociedade em relação aos escravos. ${ }^{18}$ Essa atitude pode ser percebida nas exortações ao bom tratamento dos escravos, à emancipação e à ajuda para que conseguissem adquirir a liberdade. A postura corânica em relação à escravidão refletiu o desejo de criar uma poderosa comunidade de crentes que sobrepujasse a estrutura árabe baseada em clãs. Foram sobremaneira significativos os aspectos particulares dos antecedentes culturais enfatizados pelo Corão. Embora houvesse paralelos entre cristãos, judeus e romanos, a visão corânica da escravidão não se enquadrou em nenhum padrão existente, mesmo porque nenhuma dessas culturas foi tão claramente favorável à manumissão. Por último, o cristianismo pode ter enfatizado a igualdade dos escravos em termos religiosos, o judaísmo, reduzido as punições de adultério aos escravos, e os romanos proibindo a prostituição escrava, mas somente o Corão combinou esses três elementos e provavelmente estabeleceu a legislação escrava mais progressista no seu tempo.

\section{Etnicidade e religião: estruturas complementares}

Os exemplos analisados demonstram padrões estabelecidos nos primórdios dos códigos legais islâmicos. A escola maliquita, como já foi observado anteriormente, exerceu uma grande influência no Magrebe e na 
África Ocidental. No século XVIII, Ahmad Baba de Tombuctu escreveu o Mirraj al-su’ud, segundo Hunwick, um tratado único no século XIX, que discutiu extensivamente a etnografia religiosa na África Ocidental com questôes fundamentais como quais seriam os indivíduos passíveis de escravização e suas justificativas legais. ${ }^{19} \mathrm{O}$ tratado foi utilizado pelo reformador fula Shehu Uthman dan Fodio, que o citou no seu texto sobre escravidão, Bayian wujub al-hijra, atualizando as questóes sobre os muçulmanos e os não-muçulmanos nas terras hauçás. ${ }^{20}$ Segundo Hunwick, o manuscrito foi presumivelmente produzido em Tuwat, levando-se em consideração que era endereçado aos estudiosos da região e também do Marrocos, onde Ahmad Baba era conhecido e respeitado e afinal aonde vários manuscritos de sua obra foram encontrados. ${ }^{21}$

$\mathrm{Na}$ introdução de sua obra, Ahmad Baba reproduz uma fatwa de Makhluf Al-Balbali sobre os escravos do Sudão:

A origem da escravidão é a descrença. Os infiéis do Sudão são como esses cristãos, exceto aqueles sudan ${ }^{22}$ considerados majus. ${ }^{23}$ Para lembrá-lo que entre eles os povos muçulmanos de Kano, alguns de Zakzak, de Katsina, de Gobir e todos de Songhai, todos são muçulmanos e, portanto, não podem ser legalmente adquiridos. ${ }^{24}$

De acordo com essa fatwa, a escravidão estava definitivamente ligada ao status religioso do indivíduo, salvo exceções. É importante, no entanto, ressaltar que a identidade muçulmana dos indivíduos não estava totalmente clara. Esta questão foi debatida continuamente nos tratados jurídico-religiosos elaborados pelos doutores da lei islâmica. Portanto, na tentativa de ser o mais preciso possível, a categorização era religiosa e étnica.

O próprio Ibn Khaldun, cujo trabalho foi largamente utilizado como referência pelos juristas islâmicos, citando a maldição mencionada na Torá, afirmava que não havia menção à "negritude". A maldição à escravidão limitava-se aos descendentes de Cam. Atribuir, segundo ele, a "negritude" a Cam revela equívoco da influência do clima sobre os seres humanos. Portanto, a cor da pele estava ligada às condiçôes climáticas e da adaptabilidade dos seres humanos ao meio em que viviam. Quando Ibn Khaldun comparou certos povos negros a bestas, não anatematizou estes em particular, pois incluiu os alvíssimos eslavos nesta categoria. Os abissínios, os 
povos do Mali e de Tacrur, por exemplo, eram igualmente negros. Os primeiros eram cristãos e os últimos muçulmanos; no entanto, esses povos negros foram categorizados de forma distinta. Em outras palavras, é um equívoco racializar de forma estrita os conceitos de Ibn Khaldun. ${ }^{25}$

O historiador muçulmano em geral estava de acordo com os padrões islâmicos que enfatizavam o status religioso como preponderante para determinar a legalidade de escravidão, aliás o erudito de Túnis foi muito além, elaborando uma interpretação refinada e complexa da visão do homem sobre o "outro".

Em outra passagem traduzida por Hunwick do manuscrito de Ahmad Baba, Al-Jirari em documento aparentemente anterior ao Miraj al-Su'ud, endereçou algumas questões tratadas posteriormente por Ahmad Baba. São questôes sobre os grupos étnicos ou os povos que poderiam ser escravizados legalmente. Vários grupos são listados e, além disso, al-Jirari levanta delicada questão em que os governantes de Songhai estariam escravizando grupos que pagavam tributos e, portanto, estariam a salvo das incursões dos preadores de escravos. Hunwick argumentou na sua análise dos documentos que, embora Ahmad Baba pudesse ter respondido às perguntas de alJirari no seu exílio no Marrocos entre 1593-1608, não seria surpresa se Ahmad Baba, devido à natureza polêmica das questôes, nunca tivesse respondido a al-Jirari. Este em sua carta faz algumas considerações reveladoras e complexas sobre a escravidão no Islã de acordo com as fontes tradicionais.

No caso de não se saber ao certo seu status, origem e se sua conversão foi anterior à captura, seria legal comercializar o indivíduo sem uma completa investigação? Essa investigação é compulsória ou recomendada? Qual seria o procedimento se chegasse a uma decisão dúbia? O que manda a lei? A palavra do escravo deve ser aceita ou não? Se a questão resultar em dúvida sobre o impedimento da escravização, ela deve ser anulada? Como é a jurisprudência estabelecida nos casos de divórcio e manumissão? Ou como proceder na dúvida sobre o estado de impureza após saber da necessidade do estado de pureza ser obrigatório? Ou no caso de se renunciar à retaliação quando um pai que matou o filho com uma lança não for condenado à morte devido à dúvida de sua intencionalidade. Sob que condições a retaliação seria necessária, devido à grande afeição e compaixão do pai?

Em uma das respostas do jurista Abu Ishaq b. Hilal, ${ }^{26}$ ele estabeleceu sua discordância afirmando que esses crimes provêm de ações inescrupulosas e, 
portanto, pode ser problemático imputar a esses delitos a dúvida sobre as condições em que foram cometidos. Al-Qarafi endossou a validade desses princípios na Dhakhira na parte que trata do consenso. ${ }^{27} \mathrm{~A}$ única diferença de opinião foi quanto à aplicação do princípio. Entretanto, isso depende da definição de 'dúvida'. Para al-Hilali, 'a dúvida é o conflito de duas possibilidades'. Esta definição se baseou no dito do Profeta (a paz e as bênçãos sobre ele): 'O que é permitido é claro, o que é proibido é claro. O que fica entre esses conceitos é duvidoso, e sobre o qual muitos podem discorrer' ${ }^{28}$

A escravidão, como pode ser percebido, atormentava os juristas islâmicos. São levantadas questôes jurídicas complexas sobre o dolo e a culpabilidade, interpretações legais divergentes e convergentes. Todavia, não há dúvida a respeito da discussão em torno da afiliação religiosa. $\mathrm{Na}$ fatwa "O acesso ao caminho da compreensão da Lei referente aos Negros capturados", do próprio Ahmad Baba, ele estabelece o mesmo discurso centrado no binômio religião/etnia. ${ }^{29}$

No final século XVII, no Marrocos, ocorreu uma amarga discussão entre dois eruditos islâmicos envolvendo a escravização de indivíduos para fins militares na região de Marrakesh. Sidi Muhammad ibn Abdal Qadir al-Fasi, defendendo uma investigação mais apurada antes da captura de indivíduos de status desconhecido, escreveu ao ulemá de Fez afirmando:

... a liberdade é a condição básica do homem, se o status-escravo do indivíduo não pode ser estabelecido com precisão, apenas se pode afirmar que o indivíduo é senhor de sua alma. Portanto, ninguém tem autoridade sobre esse indivíduo e ele não pode ser comprado ou vendido. Essa opinião é baseada no Kitab (livro, o Alcorão), na sunnah (tradição) e na Ijma (consenso dos eruditos). ${ }^{30}$

Por outro lado, M. Ismail, que estava encarregado de capturar e alistar escravos sob o regime alauíta no Marrocos, alegava ter recebido aprovação do ulemá do oriente e que realizava uma cuidadosa investigação com evidências concretas da origem escrava do indivíduo. Essa discussão sobre o status desses negros recrutados compulsoriamente se estendeu por meio de fatwas condenando veementemente a escravização de negros muçulmanos. ${ }^{31}$

Cerca de dois séculos mais tarde, em meio um novo turbilhão reformador islâmico, Uthman dan Fodio incluiu na sua agenda políticosocial suas preocupações com a escravidão, particularmente a escravização 
de muçulmanos e as restrições à conversão de escravos ao Islã. ${ }^{32}$ Segundo B.G. Martin, Uthman dan Fodio foi o homem talhado para promover a revolução da comunidade islâmica no Sudão Central. Ele era originário de um tradicional clă torodbe, cujos ancestrais imigraram paras as terras hauçás no século XV. Erudição e intelectualidade eram partes integrantes do seu mundo. Ele foi instruído em estudos do texto corânico, na gramática árabe, na lei maliquita e em todas as demais tradiçôes islâmicas. De acordo com os costumes clânicos, estudou com seus tios letrados. Porém, esse conhecimento familiar foi suplantado pelos mestres tuaregues do sul do Saara. Entre esses estava Jibril bin Umar al Aqdasi, que havia realizado o hajj duas vezes e vivido no Egito por longo tempo. Jibril iniciou dan Fodio em três ordens sufis, a Qadiria, Khalawatia e Shadilia. ${ }^{33} \mathrm{O}$ mestre de dan Fodio assumiu uma atitude intolerante em relação aos "pecados graves", segundo ele, cometidos por muçulmanos. A doutrina de Jibril estava próxima das escolas teológicas islâmicas medievais Khawaji e Mu'tazila. Uthman dan Fodio, no entanto, iria futuramente discordar das idéias do seu mestre e estabelecer uma ortodoxia menos radical. ${ }^{34} \mathrm{O}$ contexto permite entender as possíveis motivaçôes e influências que serviram de pano de fundo para a política dos líderes de Socoto e para suas ações sobre os muçulmanos cativos. ${ }^{35} \mathrm{O}$ s reformadores islâmicos procuravam estabelecer parâmetros para definir quem era muçulmano. Esta categorização, todavia, revelou-se delicada e a escravização se tornou alvo de intenso debate intelectual. Com o início das hostilidades que deram origem ao califado de Socoto, essa questão se resolveu de forma pragmática passando a definir os padróes de escravização em termos práticos de apoiar ou não o jihad. De forma análoga ao que foi constatado no século XVII com Ahmad Baba, no século XVIII e XIX ocorreram sofisticados debates intelectuais sobre a definição de um padrão de comportamento e práticas islâmicas. Uthman dan Fodio na sua obra Tamiyz al-Muslim min al-kafirin evitou polêmicas teológicas e escreveu seu texto "para ser entendido pelos leigos" estabelecendo oito categorias de indivíduos existentes no Sudão Central:

"O ulemás cuja fé é sólida; eles realizam ghus (ablução maior) depois da janaba (um estado de maior impureza ritual); eles realizam a ablução (com água) antes das orações e não utilizam o recurso do tayammum (ablução alterna- 
tiva com areia) exceto em casos de necessidade; eles abandonaram qualquer vestígio de descrença, como veneração de pedras, árvores, sacrifício de animais. ${ }^{36}$ Os que não negavam nenhuma parte da shari’a. Esses são definitivamente muçulmanos.

1- Os talaba (os que fazem exatamente como os ulemás acima) são definitivamente muçulmanos.

2-Aqueles que ouvem e praticam os preceitos estabelecidos pelos ulemás e os talabas.

3- Os infiéis que nunca aceitaram o Islā, ${ }^{37}$ nesse caso são claramente infiéis. 4- Os que misturam práticas infiéis e islâmicas. São definitivamente infiéis. ${ }^{38}$ 5- A sexta categoria, como a quinta, mescla práticas pagãs com islâmicas e negam (algumas) determinações da shari’a. São também infiéis.

6-A categoria dos inovadores (bida). Os juristas emitiram parecer sobre essa categoria, porém existe um consenso que se trata de muçulmanos desobedientes.

7-As pessoas ignorantes que abraçaram o Islã sem possuir conhecimento suficiente. Afirmam sua Fé sem acreditar e não se interessam em aprimorar seus conhecimentos." 39

As primeiras três categorias eram constituídas de bons muçulmanos que aderiram consideravelmente à shari’a. A quarta, de muçulmanos completamente infiéis. Movendo-se para o centro da escala, a sétima era formada por muçulmanos desobedientes e a oitava de ignorantes. Na quinta e na sexta estavam os sincréticos, os primeiros mesclando práticas islâmicas com pagãs e os últimos desprezando o Islã e negando alguns princípios básicos.

Note-se porém que o tom moderado usado no documento sugere que sua compilação tenha acontecido no período pós-jihad. Ou seja, essa datação é fundamental em uma análise de quem visa estabelecer padrões de islamização na diáspora africana. Qualquer tentativa que não leve em consideração a historicidade dessas definiçôes é imprecisa e incompleta. As definiçôes historicamente não se concretizaram de forma monolítica, nem mesmo dentro de um curto espaço de tempo. Antes e durante o conflito, esses parâmetros variaram de acordo com as agruras do conflito. É, portanto, compreensível que uma vez encerrado os combates, o líder fula tenha tido atitudes mais conciliadoras na tentativa de estabelecer uma pax islamica no Sudão central, o que aliás não ocorreu. Seria interessante identificar, segundo El Masri, em que localidades do Sudão Central havia efe- 
tivamente uma maioria islâmica receptiva ao discurso reformador de dan Fodio e de sua entourage. Essa classificação, no entanto, não pode ser feita com as fontes disponíveis, e dessa maneira uma categorização mais pragmática foi feita em termos étnicos. ${ }^{40}$

O padrão de definição étnico-religioso não constitui novidade no mundo islâmico nem deixou de ser utilizado nos dias atuais. Como já foi citado anteriormente, existiu um objetivo claro na revelação corânica em criar uma comunidade coesa de crentes além dos limites de uma sociedade árabe tribal. A expansão islâmica foi incorporando paulatinamente diferentes povos e culturas. Mesmo levando-se em consideração o caráter universalista do Islã, a identidade étnica sempre forneceu a amálgama necessária quando a definição religiosa se revelou inconclusa. Fredrick Barth enfatizou:

... que os sistemas que têm em comum o princípio de que a identidade étnica implica uma série de restrições quanto aos tipos de papel que um indivíduo pode assumir, e quantos parceiros ele pode escolher para cada tipo de transação. ${ }^{41}$ Em outras palavras, se consideramos uma identidade étnica como status, este será superior em relação à maioria dos outros status e definirá a constelação permissível de status, ou personalidades sociais, que um indivíduo com uma dada identidade étnica pode assumir. Neste sentido, a identidade étnica é semelhante ao sexo e à posição social, pois ocasiona restrições em todas as áreas de atividade e não apenas em determinadas situaçôes sociais. ${ }^{42}$

Na tentativa de desatar o nó antropológico, no caso islâmico é preciso destacar algumas particularidades. Toda a tradição profética dos hadiths enfatizou a igualdade entre os crentes. Não há justificativa nas fontes islâmicas para qualquer superioridade étnica ou tribal. ${ }^{43}$ Esta premissa, porém, não se traduziu inteiramente em termos práticos, ao contrário, serviu de complemento na categorização dos muçulmanos. Existe também um fator fundamental que foi a utilização do idioma árabe como vernáculo sagrado disseminado pela revelação corânica, que obrigou os povos convertidos a possuírem, no mínimo, rudimentos lingüísticos do árabe e, conseqüentemente, alguns dos seus hábitos culturais. A precedência de uma etnia sobre outra na aderência ao Islã passou a ser considerada um status superior, mas de forma nenhuma determinante em termos de limite do indivíduo. 
$\mathrm{Na}$ contramão da afirmação de Barth, a identidade étnica não pode ser comparada com o gênero. De forma análoga, a comparação com a posição social procede, pois ambos, status étnico e social possuem mobilidade e são passíveis de mudança. O gênero, ao contrário, tem limites claramente definidos tanto no que diz respeito a deveres, direitos e espaço social.

O caso dos pathans do Afeganistão estudado por Barth é emblemático. Segundo ele, é condição sine qua non para um pathan ser um muçulmano ortodoxo. Neste caso, o termo ortodoxo tem a conotação de praticante e sunita. Os pathans possuem um ancestral putativo que foi a Medina, onde encontrou o Profeta e se converteu. A partir dessa tradição, a etnia pathan reivindica uma adesão de "primeira hora" e evitando um histórico de conversão tardia como conseqüência de uma expansão manu militare. ${ }^{44}$

$\mathrm{O}$ código de vida e os costumes são fundamentais para se definir um indivíduo como pathan. A língua é apenas um dos elementos na construção dessa identidade, mas não a mais importante. Paradigmaticamente por intermédio do exemplo pathan, pode se entender outros grupos de povos islamizados e concluir que identidades podem ser construídas além dos limites de grupos lingüísticos. Neste caso, os pathans se autodefinem como sendo pashto não aquele que apenas fala pashto; neste sentido, "agir como um pashto significa viver de acordo um código um bastante severo, em termos do qual alguns falantes de pashto claramente estão excluídos". ${ }^{45}$

$\mathrm{O}$ xarifismo magrebino e subsaariano também podem ser vistos superficialmente como uma forma de estabelecer um status islâmico superior. A descendência do Profeta podia determinar uma aceitação de liderança inconteste e uma ascensão social indispensável para clérigos sob certas circunstâncias. ${ }^{46}$ Não obstante, em muitas ocasiōes, essas discussões tornarem-se estéreis e alvo de controvérsias. Todavia, o xarifismo assumiu contornos endêmicos durante o século XIX nos variados movimentos que assolaram a África islâmica. ${ }^{47}$

Portanto, a categorização étnico-religiosa de Ahmad Baba no século XVII não era a mesma de Uthman dan Fodio no século XIX. Em dois séculos, novas populações foram incorporadas ao Islã e as definições experimentaram mudanças de acordo com as necessidades políticas. Havia três grupos étnicos majoritários na Hauçalândia: hauçás, tuaregues e fulas. As três etnias possuíam grupos islamizados e não-islamizados e, de acordo com 
El Masri, os fulas eram a etnia que exibia níveis de islamização e erudição mais sofisticados. ${ }^{48}$ Tanto dan Fodio como seu filho Muhammad Bello citavam as fatwas de Ahmad Baba que enfatizavam o papel preponderante dos fulas nos assuntos islâmicos. No entanto, os pastores e os fulas Sullebawa eram pagãos ou apenas nominalmente muçulmanos. Não sendo possível perceber em nenhuma etnia subsaariana uma identificação absoluta com o Islã, foi necessário recorrer à etnicidade como parâmetro no intuito de classificar os indivíduos.

De acordo com Jibril ibn Umar, mestre de dan Fodio por volta de 1800 , a "venda de homens livres" era proibida porque era sabido que muçulmanos estavam sendo escravizados e vendidos. Para Jibril, a escravização de muçulmanos, o adultério, o consumo de álcool e o assassinato eram crimes similares e gravíssimos.

Uthman dan Fodio, na sua obra Masail il muhimma, em 1812, estabeleceu que a escravização de qualquer fulas era ilegal. Esta premissa era baseada no fato de que havia um consenso de que os fulas eram identificados de longa data com o Islã. Era, portanto, segundo ele, a interdição destas práticas que distinguia os muçulmanos. ${ }^{49} \mathrm{O}$ poema em língua fulfube Tabbat hakika previa que "aquele que escravizar um homem livre deverá ser atormentado. O fogo do inferno o escravizará, fique certo disso!". ${ }^{50}$ No documento considerado como o manifesto do jihad de Socoto, dan Fodio proclamou que a escravização de indivíduos livres de nascimento entre os muçulmanos era ilegal, quer residissem em território islâmico ou em território inimigo. ${ }^{51}$ A preocupação óbvia dos líderes do jihad com a escravização considerada ilegal parece refletir uma prática intensa desta atividade. Muhammad Bello escreveu no Miftah al-Sadad que a escravização de fulas não era legal, a despeito de existir no Sudão Central fulas não-muçulmanos. ${ }^{52}$

Os movimentos reformadores islâmicos no Sudão Central foram processos consideravelmente complexos. Esses movimentos revelam o ápice do papel dos clérigos na difusão e reforma do Islã nas áreas em questão. Com os eruditos religiosos sempre ligados a irmandades e detentores de um conhecimento islâmico refinado, a reforma ganha contornos aparentemente conflitantes: o Islã militante e intelectualizado, a proteção e a redenção de muçulmanos e o combate ao tráfico de muçulmanos escravizados. Simultaneamente, o tráfico aumentou consideravelmente com a oferta 
crescente de indivíduos originários de uma região de conflito e uma demanda igualmente crescente do tráfico atlântico. Pode-se detectar como motivo do intenso debate jurídico-intelectual as tentativas de se delimitar os parâmetros religiosos dos indivíduos. Em outras palavras, fixar padrões religiosos era a referência que podia determinar os indivíduos passíveis de escravização. Como foi observado em outras ocasiōes, essas tentativas não obtiveram êxito. Foi igualmente necessário imputar padrões de etnicidade simultaneamente aos conceitos religiosos historicamente dúbios.

Segundo a teoria de Levtzion, quando os clérigos assumem o poder, o Islã torna-se militante, reformador e revolucionário. Sem dúvida, de acordo com esse paradigma, o modelo pode ser aplicado em termos gerais a todos os movimentos reformadores islâmicos na África do século XIX, e no século XX a movimentos contemporâneos no Sudão, no Irã e no caso específico da ascensão da comunidade xiita libanesa. ${ }^{53}$

De volta aos jihads do Sudão Central, o conflito intenso, nas terras hauçás inicialmente e posteriormente em direção à Iorubalândia, no moribundo estado de Oió produziu prisioneiros de diversos extratos sociais e religiosos. Portanto, o tráfico não distinguiu aristocratas de camponeses, nem eruditos de indivíduos parcialmente islamizados ou de adeptos das religióes tradicionais africanas. A trajetória desses indivíduos em terras americanas faz parte de uma nova realidade que abrange um leque de atitudes, da acomodação à rebelião. Adotando uma perspectiva africanista e um fluxo mais dinâmico no Atlântico, as áreas diversas do continente americano em que esses indivíduos se instalaram possui uma relevância limitada. Ao inverter a perspectiva dominante, o enfoque aqui proposto demonstra que esses africanos adultos e saudáveis priorizados pelo tráfico atlântico não se "criolizaram” facilmente, mas ao contrário, buscaram intensamente estabelecer em seus mundos as suas práticas sob condições quase sempre adversas. ${ }^{54}$

De forma análoga, um aspecto que pode ser percebido em Salvador em 1835 é que os clérigos eruditos e intérpretes da lei assumem a direção dos destinos da comunidade. Dentro de um padrão historicamente coerente, o Islã tornar-se-á militante, organizado de em torno de um liderança letrada e de acordo com os padróes de uma confraria rebelde.

Quando o profeta Muhammad conquistou a cidade de Meca, ordenou que Bilal, o muezim africano liberto, fizesse o chamado (azzan) para 
a oração. ${ }^{55} \mathrm{O}$ chamado melodioso e comovente de Bilal ecoou por séculos cruzando desertos, savanas e florestas até atingir as margens da costa africana do Atlântico. ${ }^{56}$

De acordo com Keneth Harrow, a literatura islâmica busca localizar identidades muçulmanas em indivíduos conscientes dessa condição, na condição arautos ou críticos, mas que refletem indubitavelmente em seus escritos, um discurso identificado com o Islã. ${ }^{57}$ A literatura islâmica surgiu da interseção entre cultura, discurso, texto e leitor. Isto se dá em relação a textos específicos, assim como leitores a específicos, e às maneiras pelas quais o idioma foi empregado para construir textos e idéias relacionados.

A história da escrita islâmica na África pode ser concebida como desenvolvimento das suas relações com o Oriente Médio e o Magrebe. Por estar geograficamente distanciada das terras centrais do Islã, a literatura africana ficou caracterizada pelo sincretismo e exposta a empréstimos da cultura local. As formas mais antigas podem ser entendidas como arabocêntricas, em que a tradição do Islā "puro" parece ser extraída do âmago da civilização árabe e em contraste com as formas "impuras” e impregnadas de tradições subsaarianas que fazem parte do processo de naturalização do Islã em terras africanas. Na África, como alhures, existia um estado de tensão permanente entre a pureza e a impureza da literatura islâmica. Entretanto, sob uma perspectiva menos preconceituosa, o rebaixamento sincrético tão deplorado pelos puristas é uma característica do desenvolvimento de um pensamento islâmico por intermédio de um processo histórico no Islã subsaariano.

Ao sul dos reinos de Mali e de Songai, floresceram centros urbanos onde o Islã se estabeleceu gradualmente principalmente a partir do século XV. As cidades hauçás de Kano e Katsina tornaram-se centros de intensa atividade islâmica. A tradição oral da Hauçalândia foi preservada através da memória dos antigos movimentos reformistas, como pode ser visto no desenvolvimento dos labarai (narrativas orais). Em uma narrativa, em particular, relata-se o confronto promovido por um soberano entre um sacerdote bori e um mallam muçulmano. O soberano em questão colocou um cavalo dentro de uma casa sem que ninguém mais tivesse conhecimento do fato. Em seguida perguntou ao sacerdote bori o que havia na casa; o sacerdote respondeu que era um cavalo. Quando formulou ao mallam a 
mesma pergunta, este pediu a orientação de Allah e respondeu de forma totalmente diferente: dentro da casa havia um touro branco com chifres. O soberano na expectativa de encontrar o cavalo, ordena que se derrube as paredes da casa. Para espanto do soberano, um touro branco com chifres foi encontrado. $\mathrm{O}$ soberano esperou em vão por anos pela transformação do touro em cavalo e por meio desse milagre, Allah assegurou o triunfo da verdadeira fé em Katsina. ${ }^{58}$

O confronto entre o sacerdote bori e o mallam estabeleceu a estrutura-padrão encontrada em muitas tradições orais africanas: a disputa entre poderes mágicos como elemento central. O primeiro significado dessa disputa dialética é o triunfo do poder em decorrência da vitória do mallam. A transformação mágica da besta sugere hermeneuticamente a intervenção divina vinculada a importantes questôes de contenda, jihad e interpretação (ijtihad). A subordinação da identidade da besta à vontade de Allah e a demolição do muro da casa cercam a milagrosa transformação que, simultaneamente, sugere significados místicos compatíveis com a tradição literária da sabedoria islâmica. A inclusão dessa parábola no contexto específico da narrativa oral sobre a conversão dos hauçás de Katsina demonstra aceitação do Islã por parte do soberano em um importante centro urbano onde ocorreram os grandes jihads do século XIX.

Curiosamente, muitos sacerdotes bori de Kano que se confrontavam com os mallans de Katsina eram também muçulmanos. A narrativa enfatiza soluções absolutas quando proclama: "Somente o Islā. O Islã e nada mais". O Islã surge como vitorioso e conquistador em um primeiro momento, mas o próprio texto deixa transparecer existência de um discurso religioso preexistente. ${ }^{59}$ Essa narrativa oral pode ser interpretada sob dois aspectos principais: o primeiro e mais explícito da conquista e disseminação do Islã pelos mallans, e o segundo, de forma mais implícita, do triunfo de Katsina sobre Kano.

De acordo com alguns autores, o Islã foi aceito com relativa facilidade na África devido a sua similaridade com a cosmologia das religiōes indígenas. ${ }^{60}$ Owasa-Ansah, no entanto, não concorda com essa premissa aplicada de forma genérica, mas reconhece que, no caso específico das preces e amuletos, a teoria da similaridade se encaixa perfeitamente. ${ }^{61}$

Os manuscritos produzidos pelos africanos muçulmanos na Bahia podem ser definidos, de modo geral, como a reprodução de textos corânicos 
e du'ass. ${ }^{62}$ Em alguns documentos encontram-se fórmulas e desenhos que indicam a utilização de conhecimento esotérico (ilm al-batin). Como os chamados "papéis árabes" poderiam esclarecer os pontos ainda obscuros da revolta? As traduções feitas pelo hauçá Albino, por Monteil e por Reichart praticamente dissecaram os manuscritos. O objetivo do trabalho não foi reexaminar os referidos manuscritos e deduzir alguma ordenação lógica ou significados pela análise das suratas (versículos corânicos) e du’as (súplicas). Concentramo-nos em trabalhar com manuscritos pouco trabalhados e com interpretações incompletas. A exegese desse corpus documental faz inegavelmente parte da literatura produzida no Brasil no século XIX, buscando documentos e motivaçōes similares produzidos na África e no Oriente Médio. A análise dos manuscritos constitui um manancial riquíssimo de informações; por isso ressaltamos que a pesquisa de Monteil/Reichert não esgotou as possibilidades de análise dos manuscritos do Arquivo da Bahia como fonte histórica. Todavia, por questôes relacionadas à delimitação e extensão do presente trabalho, fizemos a opção por enfatizar um corpo documental em detrimento do outro. Existem dois corpos principais de documentos manuscritos em árabe no Brasil: o primeiro, já mencionado e traduzido que se encontra no Arquivo Público de Estado da Bahia; e o segundo que se encontra no Instituto Histórico do Rio de Janeiro no Rio de Janeiro, traduzido recentemente e que será objeto do nosso estudo. ${ }^{63}$

Segundo Diouf, um grande número de muçulmanos chegou ao Novo Mundo alfabetizado em árabe e nos idiomas africanos que utilizavam o alfabeto árabe. Em contrapartida, outros grupos de africanos se originaram de culturas orais e a alfabetização entre escravos na América era desencorajada. Desse modo, a capacidade de ler e escrever tornou-se uma distinção dos escravos muçulmanos. ${ }^{64}$

De acordo com Austin, a maioria dos senhores de escravos precisava suprimir práticas que pudessem ser usadas para unir ou orientar os cativos. Se necessário, estabeleciam estratégias para cooptar determinados indivíduos, reconhecendo e recompensando suas habilidades supostamente excepcionais com um poder limitado sobre os outros escravos. ${ }^{65}$

O escritor e etnólogo William Hodgson, que viveu na África do Norte, tentou realizar uma pesquisa sobre os escravos muçulmanos alfabetizados na América do Sul. Hodgson, no entanto, foi pressionado a abandonar a tarefa devido à hostilidade dos donos de escravos. Segundo Hodgson, 
a hostilidade dos proprietários de escravos brasileiros não se devia apenas ao já conhecido perigo potencial da literatura entre os africanos muçulmanos. Esta animosidade, aos olhos escravistas, advinha da ameaça ao domínio intelectual senhorial baseado na premissa da inferioridade inerente ao africano, e sua conseqüente incapacidade de produzir manifestações eruditas. Estas habilidades intelectuais constituiriam um reconhecimento tácito de humanidade e civilização originais e, portanto, sem nenhuma relação com o cristianismo e seu suposto projeto civilizador. $O$ fato de esses indivíduos possuírem a capacidade de ler e escrever revelava uma imagem que não condizia com a do selvagem primitivo e, conseqüentemente, passível de ser escravizado. A partir da desmistificação dessa premissa, os fundamentos do sistema escravista podiam ser questionados. ${ }^{66}$ De acordo com Diouf, esse argumento se revelou tão poderoso que nos Estados Unidos adotou-se um subterfúgio no mínimo original. Os norte-americanos passaram a negar a origem africana desses muçulmanos "excepcionais", retratando-os como árabes ou mouros. ${ }^{67}$

Goody ressalta o poder da cultura escrita sobre a cultura oral, o poder que permite a primeira de dominar a última em vários aspectos. Este processo envolve algumas mudanças em nossas operações cognitivas, nesse caso com ajuda de textos e por meios denominados "tecnologias do intelecto". $\mathrm{O}$ poder da escrita pode se fundamentar sobre vários elementos dentro de uma sociedade em particular. Isso abrange não apenas o poder hegemônico que controla os meios de comunicação dos grupos dominantes, e freqüentemente os religiosos, mas também os dominados que podem se utilizar desses meios para se inserir no meio ambiente social. Ele considerou paradigmático o exemplo dos escravos e libertos africanos na Bahia no inicio do século XIX. ${ }^{68}$

Ainda de acordo com Goody, as religiōes de tradição oral não convertem o indivíduo, apenas o tornam membro de um sistema político (tribo) e limitam-no, em grau maior ou menor, às crenças do grupo. Conversões, portanto, envolvem um conceito diferente de religião que exige comprometimento com textos estabelecidos (crenças e rituais) e envolve a renúncia de um conjunto de práticas em favor de outras. Dessa forma, o Islã tornou-se um aparato supra-étnico. ${ }^{69}$

O tráfico escravo não fez distinção social entre os indivíduos trazidos para a América, mas a demanda americana possuía seus próprios padrões. 
Por outro lado, a oferta africana, no caso específico da África Ocidental, devido às contingências de um conflito intermitente e à dinâmica do seu tráfico interno, igualmente lançou indivíduos dos mais variados extratos sociais no tráfico atlântico.

O resultado dessa disparidade social refletiu-se no nível de educação e conhecimento adquiridos em terras africanas e na produção dos textos manuscritos encontrados em épocas e situações diversas. As condiçōes adversas da escravidão dificultaram sobremaneira o desenvolvimento de uma comunidade com liberdade de praticar a religião publicamente. Todavia, a produção intelectual dos africanos muçulmanos na América foi provavelmente muito maior do que a maioria das pessoas imagina ou mesmo mais significativa do que os especialistas possam aceitar. ${ }^{70}$

O estudo do conhecimento islâmico enfoca basicamente ensaios e comentários. Os estudiosos muçulmanos freqüentemente lêem e discutem os trechos clássicos, adquirindo assim um conhecimento genérico da história islâmica, tratados jurídicos e assuntos relacionados com a devoção religiosa. Esta tradição literária estava profundamente arraigada na África Ocidental e sabidamente espalhou-se no Novo Mundo. ${ }^{71}$

Os africanos muçulmanos enviados pelo tráfico podiam ser jovens ainda com conhecimentos rudimentares das primeiras letras corânicas, professores, ulama ou marabutos eruditos. ${ }^{72}$ Os segmentos mais dinâmicos da população muçulmana eram constituídos por indivíduos eruditos, viajados, cosmopolitas e poliglotas. Em outras palavras, indivíduos com recursos, mesmo sob condiçôes adversas e em terras estranhas. De acordo com Diouf não há dúvida que muçulmanos iletrados foram enviados para a América, mas certas passagens sobre a vida desses muçulmanos atestados em documentos indicam a presença de um numero significativo de indivíduos oriundos de uma elite intelectual. ${ }^{73}$

A educação islâmica primordialmente enfatizou o acesso do crente ao Corão, a rituais específicos, normas éticas e padrões de comportamento todos derivados da mensagem divina e da tradição do Profeta. De forma análoga transmitiu também padrões mais abrangentes além da alfabetização elementar. Proveu o estudante igualmente de direito islâmico, da teologia, do misticismo, da gramática árabe, da poesia, da literatura, da história, da aritmética, da astronomia ligada à terapias médico-mágicas. ${ }^{74}$ Esse 
complexo intricado de aprendizado que envolvia crianças e idosos possuía uma história de mais de mil anos na África subsaariana e tornou-se um importante diferencial de mediação nas sociedades africanas. ${ }^{75}$

Nas diferentes regiōes onde o Islã se estabeleceu, a educação islâmica não apenas separou as comunidades vizinhas, mas também instituiu padrões importantes de cultura comuns para muçulmanos e não-muçulmanos. Os traços desse longo idílio podem ser encontrados na língua, folclore, em lendas, vestimenta, nas datas celebradas em comum e num corpo abrangente de práticas terapêuticas e mágicas, em parte locais, em parte de acordo com padrões islâmicos. ${ }^{76}$

$\mathrm{Na}$ devassa que foi instaurada em decorrência da Revolta Malê em 1835 se encontrou uma grande quantidade de documentos escritos em árabe. A tradução do escravo hauçá Albino durante o processo criminal resumiu o conteúdo de uma parte dos papéis árabes apreendidos pelas autoridades. ${ }^{77}$

A tradução de Albino foi um na verdade um inventário dos "papéis árabes” encontrados pelas autoridades. Os exercícios de caligrafia e os amuletos foram em parte preservados. Todavia, o plano dos rebeldes no original não foi encontrado. ${ }^{78} \mathrm{~A}$ menção feita por Albino às tabuas utilizadas pelos rebeldes é um exercício de memorização corânico largamente utilizado na África Ocidental chamado wala uassa. ${ }^{79}$ Conforme Reis observou no relato do diplomata inglês Hugh Clapperton em visita ao Califado de Socoto em $1826 .^{80}$

Assim, bebendo as palavras de Allah nas ile kewu, ${ }^{81}$ os africanos na Bahia também memorizavam e preservavam as passagens corânicas, além de obter proteção mística. Da mesma forma que jejuavam durante o mês de Ramadã e bebiam as "palavras de Deus" na quebra do jejum (ifhtar) ao anoitecer. ${ }^{82}$

Danmole enfatizou o uso de amuletos pelos mudjadeens do emirado de Ilorin na Iorubalândia setentrional.O recurso desses artefatos era comum na Nigéria pré-colonial e na África Ocidental em geral. Em Ilorin os mallans estavam profundamente envolvidos com os negócios da guerra. ${ }^{83}$ Os religiosos confeccionavam os artefatos chamados ondè yfunpá, assim como outros amuletos para os guerreiros. ${ }^{84}$ Todos os amuletos eram feitos com textos corânicos. Além desses amuletos, os soldados de Ilorin carregavam um calabash contendo remédios que assegurariam a vitória das tropas 
islâmicas (al-jamat islamiya). Outros amuletos eram enterrados por espióes em território inimigo com o objetivo de inutilizar suas armas. Uma substância líquida chamada hantu era também espalhada para enfraquecer os inimigos. As preces e outras atividades espirituais aparentemente contribuíram de forma decisiva na performance militar do exército de Ilorin e de outras regiōes da Nigéria. Através das preces o moral das tropas atingia o ápice. Danmole observou:

As preces também preparava-os psicologicamente para os perigos do combate. A crença na eficácia dos amuletos e das preces contribuíam para que os guerreiros exibissem uma sensação de invencibilidade. Talvez a vantagem psicológica mais importante das preces e amuletos por parte dos exércitos do emirado tenha sido a crença que a perda da vida no campo de batalha seria recompensada abundantemente no Paraíso. Conseqüentemente, os combatentes de Ilorin marchavam para guerra no século XIX certos de que Deus estava com eles. ${ }^{85}$

É importante ressaltar que a confecção de amuletos por mallans para guerreiros não estava restrita a Ilorin. Os guerreiros de outras partes da Iorubalândia também utilizavam os serviços místicos dos mallans. ${ }^{86} \mathrm{~A}$ similaridade das práticas islâmicas na África e na Bahia não deixa dúvidas da sua origem comum.

Os mesmos procedimentos místicos foram utilizados pelas tropas de Ilorin e pelos malês em Salvador. Ou seja, foram "plantados" amuletos no trajeto dos rebeldes que anulariam a eficácia das armas de fogo das tropas baianas. Sabidamente esse artifício não funcionou em 1835.

No Brasil e em Portugal, por exemplo, o amuleto conhecido como mandinga aparece no século XVIII. O termo foi freqüentemente utilizado nos processos da Inquisição contra os africanos e seus descendentes, do Brasil às ilhas do Mediterrâneo. ${ }^{87} \mathrm{O}$ relato do Francisco Gonçalves Martins, chefe de polícia de Salvador, destacou a importância dos talismãs:

O certo é que a Religião tinha sua parte na sublevação, e os chefes faziam persuadir aos miseráveis, que certos papéis os livrariam da morte, d'onde vem encontrar-se nos corpos mortos grande porção dos direitos, e nas vestimentas ricas e esquisitas, que figurão pertencer aos chefes, e que foram achados em algumas buscas. ${ }^{88}$ 
Já no Rio de Janeiro na correspondência do chefe de polícia Eusébio de Queiroz ao Ministro da Justiça Manoel Alves Branco no fatídico ano de 1835 foi relatado:

Fiz vir a minha presença um preto Nagô para interrogar a respeito dos Nagôs da Bahia e daquelle ouvi dizer que os Nagôs não sabem ler, nem escrever e mandam educar alguns rapazes em sua Nação vizinha e que usam barbas compridas no queixo, informo os quais (?) de escripta por conseqüência os escriptos não são em língua Nagô (?) outro idioma que só os Nagôs (?) entendem. ${ }^{89}$

Na correspondência policial aparecem os primeiros sinais da presença muçulmana na Corte com a apreensão do amuleto muçulmano ela polícia. De acordo com o conteúdo pode-se perceber claramente que se trata de um amuleto africano de acordo com os padróes do existentes na Bahia ou em qualquer área do mundo islâmico.

$\mathrm{Na}$ primeira parte do documento, o diligente chefe de polícia da corte relata o depoimento do africano encarregado da tradução. Este parece confirmar a assertiva de alguns depoimentos dos processos na Bahia. Os nagôs não possuíam erudição suficiente nos assuntos islâmicos e mandavam educar seus jovens em estados islâmicos vizinhos..$^{90}$

$\mathrm{Na}$ interpretação de Líbano Soares, o amuleto revelou além das propriedades protetoras inerentes ao artefato, uma distensão interna dos africanos. Corroborando essa interpretação e aprofundando um pouco mais a discussão, os estudiosos da diáspora muçulmana têm desenvolvido a teoria da existência de duas correntes de resistência islâmica escrava na América. Essas distensões aparentemente não foram suprimidas em face da opressão da escravidão e, conseqüentemente, os muçulmanos na diáspora não tiveram uma percepção uniforme da escravidão assim como nas estratégias de resistência para superar essa condição. ${ }^{91}$ Porém, na tentativa de entender melhor as distensões detectadas na documentação, faz sentido que esses indivíduos tenham reagido de acordo com as diferentes correntes ideológicas existentes na África Ocidental. Pode-se especular que houve por parte dos africanos muçulmanos a utilização de estratégias de acordo com afiliaçôes ideológicas e as oportunidades oferecidas pelo cativeiro. ${ }^{92}$

Uma das vertentes políticas identificadas no documento revela um comprometimento com a prática militante do jihad. Estes, na África Ocidental, condenavam a escravização de muçulmanos livres, a venda de 
escravos para os cristãos e agressivamente buscavam a imposição da lei islâmica. Todavia, o Islã na África Ocidental possuía também uma tradição de acomodação em Estados em que os governantes muçulmanos freqüentemente toleravam as práticas religiosas tradicionais dos camponeses. Esta atitude foi veementemente condenada pelos reformadores islâmicos. Wilks, por exemplo, observou essa tradição islâmica "quietista", que tolerava práticas tradicionais e em algumas ocasiōes opunha-se ao jihad. ${ }^{93} \mathrm{Se}$ gundo Willis, os "quietistas" representavam uma corrente incapaz de corresponder às expectativas reformadoras do Islã africano do século XIII da Hégira. Os mudjahidin, embebidos da austeridade revolucionária, recusaram-se a fazer concessóes. O jihad era o único caminho capaz de romper o impasse entre o Islã e a descrença. ${ }^{44}$ Uthman dan Fodio, por sua vez, também criticou severamente os mallams "quietistas", que tentavam utilizando uma postura ambígua preservar suas posições nas cortes pagãs. ${ }^{95}$ Essas assertivas pressupõem a existência de um considerável grau de animosidade entre os muçulmanos dessas duas correntes conflitantes, resultando em guerras e conflitos no interior da comunidade islâmica. A tradição "quietista" estava aparentemente ligada aos mandingos, enquanto a tradição do jihad aparece claramente ligada aos fulas, hauçás e iorubás. Na devassa que seguiu a revolta escrava de 1835 na Bahia, indivíduos recorrem ao artifício de pertencer a grupos étnicos e lingüísticos menos comprometidos com a militância islâmica, argumento que foi decisivo na tentativa de escapar do estigma rebelde dos muçulmanos hauçás e iorubas, e conseqüentemente obter a absolvição ou comutação por penas mais brandas. ${ }^{96}$ Esses exemplos foram usados de forma análoga por Austin nas biografias de escravos islamizados nos Estados Unidos no século XIX. Os indivíduos estudados por Austin integraram-se à nova ordem utilizando a erudição como forma de ascender socialmente nos estreitos limites da sociedade escrava. ${ }^{97}$ Dentre vários exemplos, podemos citar que durante a Guerra de 1812, entre Estados Unidos e Inglaterra, escravos africanos islamizados lutaram para defender as propriedades dos senhores. Esses indivíduos, nesse caso oriundos do Sudão Ocidental não pertenciam à tradição militante do jih ad. ${ }^{98}$ Em 1823, na rebelião escrava de Demerara, um capataz muçulmano denunciou os revoltosos aos britânicos. O estereótipo de escravo muçulmano endemicamente revoltoso se desfaz em meio a interpretação dialética 
acerca da prática e proselitismo das diversas correntes islâmicas na África Ocidental e na diáspora islâmica no Atlântico. ${ }^{99}$

\section{0 livrinho malê}

O documento conhecido como "livrinho malê" consiste de um amuleto manuscrito com passagens corânicas. Esse amuleto foi doado por um cidadão chamado J. de Sampaio Vianna e foi encontrado no pescoço de um revoltoso morto durante a revolta muçulmana de $1835 .{ }^{100}$

O estilo de escrita árabe magrebina é o mesmo dos manuscritos encontrados no arquivos baianos. A grafia limpa e com poucos erros indica um grau de erudição considerável. As suras em alguns trechos demonstram claramente a relação com a situação dos escravos e libertos muçulmanos na Bahia. Os versículos abrangem a maior parte do Corão (114 versículos), porém, não escritos integralmente; aparentemente os versículos e seus trechos específicos escolhidos foram selecionados deliberadamente. $\mathrm{O}$ texto se inicia no versículo 2, al-Bácara (A Vaca) e termina no versículo 69, alHácara (A Realidade). Como não se tem registro da existência de exemplares do Corão na Bahia para esse período, deduz-se, portanto, que o autor tivesse conhecimento de todo ou de grande parte do texto corânico. ${ }^{101}$

Algumas passagens corânicas reproduzem de forma incrivelmente fiel a situação da comunidade muçulmana na Bahia no período que antecedeu a revolta de 1835 :

E o que vos impede de combater pela causa de Deus e dos indefesos (mustadh'af), ${ }^{102}$ homens, mulheres e crianças? Que dizem: ó Senhor nosso, tira-nos desta cidade (Meca), cujos habitantes são opressores. Designa-nos, de Tua parte, um protetor e um socorredor! ${ }^{103}$

De acordo com esses trechos e no decorrer dos versículos, percebe-se claramente uma comunidade sob coerção além dos limites óbvios da escravidão. Tecnicamente falando, o autor demonstra não apenas o domínio do conteúdo corânico, mas uma sofisticada capacidade de analogia (qiya $)^{104}$ do Corão com a realidade. Essa habilidade é um recurso circunscrito a eruditos islâmicos.

A última parte do documento traz a transcrição da Surah Ya sin quase na íntegra. ${ }^{105}$ Seria pertinente esclarecer o significado desse versículo den- 
tro da tradição islâmica clássica e da tradição das vertentes islâmicas na África Ocidental. Ya sin são duas letras do alfabeto árabe e a sua revelação remonta ao período final da revelação profética em Meca, antes da imigração para Medina. Os versículos foram revelados no sentido de advertir o clă de Coraix das conseqüências de sua descrença, tirania e arrogância. De acordo com tradição profética, a Surah Ya sin é o coração do Corão, como, de forma análoga, a Surata al-Fatiha é a sua essência.

A utilização da Surah Ya sin na Iorubalândia podia variar de acordo com os círculos ligadas ao sincretismo, à acomodação ou à reforma. Por exemplo, na sua utilização como forma de controle adivinhatório nos círculos sincréticos do Islã com a religião tradicional. Um caso específico era a utilização da sura em questão em casos de maldição, encantamentos e insanidade. A insanidade seria causada por jinns (gênios, espíritos) e tratada com a poderosa Surah Ya sin recitada pelo alufá no ouvido do doente "com o coração e o conhecimento em uníssono que Deus é Uno". ${ }^{106}$

De acordo com a análise conjunta do corpus documental dos manuscritos preservados foi possível chegar a algumas conclusões. ${ }^{107}$ Pode-se atestar que se tratava de alguém que conhecia as regras gramaticais e por isso cometeu poucos erros. A firmeza da pena, sem hesitação, sugere que o autor era um praticante contumaz da escrita e da leitura no idioma árabe. Essas características ficam patentes na Surah Ya sin e no du'á rabbana respectivamente. Deve ser ressaltado que a vocalização não foi empregada de maneira uniforme. ${ }^{108} \mathrm{~A}$ constatação poderia significar que o autor foi obrigado, por qualquer razão, a terminá-lo sem vocalizá-lo inteiramente. Existe ainda a hipótese de o autor ter escrito o manuscrito para uso próprio; dessa forma não haveria necessidade de vocalizá-lo, especialmente no caso de textos tradicionalmente memorizados como o Corão. ${ }^{109} \mathrm{O}$ autor identifica-se como Suleiman ibn Dawuud sem erros de grafia no seu nome em árabe. ${ }^{110}$ Parte do manuscrito parece ter sido montado para ser utilizado como amuleto em uma escrita que não é árabe nem hauçá. Não obstante, o autor estar envolvido em exercícios ligados à escrita e ao conhecimento das passagens corânicas.

A análise dos manuscritos revela um considerável gama de possibilidades. Esse é um estudo preliminar, mas já aponta para algumas abordagens específicas. Os manuscritos têm sido tratados pela historiografia apenas como uma fonte auxiliar do objeto. Essa assertiva foi construída pelo 
desconhecimento da força da escrita, da poesia e da recitação no caso especifico de culturas e sociedades islamizadas.

A revelação de vertentes místicas organizadas associadas ao conhecimento místico islâmico socialmente e politicamente proeminentes, nos oferece ao menos uma opção, para perceber tais manifestaçôes dentro de uma perspectiva coerente de acordo com práticas preexistentes.

\section{Notas}

${ }^{1} \mathrm{O}$ conceito foi empregado no trabalho como uma extensa entidade supranacional de ordem jurídica, religiosa e cultural. Tradicionalmente, porém, é uma terminologia usada por legisladores islâmicos para determinar terras sobre controle de governantes muçulmanos.

2 LOVEJOY, Paul E. "Background to Rebellion: "The Origins of the Muslim Slaves in Bahia", in: Slavery and Abolition, 15, 2, 1994, p. 25.

${ }^{3}$ Segundo Brockopp, em contraste, os relatos de escravidão doméstica na Grécia antiga, Roma, Egito e Babilônia são mais completos. BROCKOPP, Jonathan E. Early Maliki Law: Ibn Abd al-Hakam and his major compedium of jurisprudence. Leiden-Boston-Köln: Brill, 2000, p.117. Os relatos mais próximos da escravidão doméstica na sociedade islâmica tratam do mercado de escravos. Esses mercados revelam importantes aspectos da escravidão como um fenômeno mais abrangente e nos permite conhecer mais sobre o tráfico escravo do que vida dos escravos domésticos. Ver: RAGIB, Yusuf. "Les Marchés aux esclaves en terre d'Islam”, in: Mercati e Mercanti nell alto medioevo. Spoleto, 1993, pp. 721-763. Ragib também relata a pseudociência da fisiognomonia pela qual os escravos eram examinados. Esse assunto é objeto do estudo de MÜLLER, Hans. Die Kunst des Sklavenkauf, nasch arabischen, persischen und türkischen Ratgebern vom 10. bis zum 18. Jahrhundert. Freiburg: i.B., 1980 e LEWIS, Bernard. Islam from the Prophet to the Capture of Constantinople. New York: Harper Collins, 1974.

${ }^{4}$ BROCKOPP, op. cit., p. 119.

${ }^{5}$ Idem, p. 208.

${ }^{6}$ Ver: HRBEK, I. "Die Slawen im Dienst der Fatimiden”, in: Archive Orienalni, 21, 1953 , pp. 543-581.

${ }^{7}$ HEFFENING, W. "Zum Aufbau der islamischen Rechtswerke", in W. Heffening and W. Kirfel (ed.) Studien zur Gestichte und Kultur des nahen und fernen Ostens. Leiden, 1935, pp. 101-118.

${ }^{8}$ BROCKOPP, op. cit., p. 148.

${ }^{9}$ Idem, p. 148. Abd Allah ibn Abd al-Hakam acrescenta que essa regra aplicava-se mesmo a escravos que pertencessem simultaneamente a muçulmanos e cristãos. Se o muçulmano emancipasse sua parte, deveria comprar a parte de seu sócio cristão. 
${ }^{10} \mathrm{O}$ escravo emancipado tem o direito de propriedade sobre seus pertences, mas no caso dos filhos, estes continuam a pertencer ao senhor. Idem, p. 151.

${ }^{11}$ Ibidem, p. 152. Abd Allah ibn Abd al-Hakam a perda da propriedade não implicava a perda dos direitos de clientela. É importante notar que essa punição específica foi além das injunções encontradas no Corão. Podem ser encontradas exceções ao bom tratamento de escravos no al-Muktasar al-kabir. Por exemplo, quando estrangeiros, sob a proteção de muçulmanos, castravam escravos em terras islâmicas. A emancipação nesse caso não era um direito. A explicação para esse caso particular de maus-tratos sugere a existência de "fábrica de eunucos" em território muçulmano. Além disso, escravas podiam conseguir a emancipação por um contrato "em troca de produção" por crianças (que seriam escravas), mas nesses casos, havia a precondição de que o procedimento não causasse danos psicológicos para a mãe. O que deixa subentendido que tal arranjo legal podia ser oneroso para a escrava.

${ }^{12}$ No caso em que as dívidas ultrapassassem os bens do escravo ou o escravo masculino (gulam) que tivesse atingido a maturidade. Ibidem, p. 152.

${ }^{13}$ Ibidem, p. 152. Ambas as fontes, cristãs e judaicas, incluem mukatab, mudabbar, o escravo maltratado, umm walad e o cego, como passíveis de serem libertados após alguns anos. Abd al-Hakam acrescentou os infantes em fase de amamentação, os portadores de enfermidades crônicas como também passíveis de manumissão, mas nesses casos específicos a decisão caberia inteiramente ao senhor. Em outra passagem, ele especifica os escravos que a propriedade não pode ser questionada legalmente: os eunucos, os mancos e os caolhos.

${ }^{14}$ De acorco com Crone, os aspectos do clientelismo romano não podem ser confundidos com os mesmos aspectos da lei maliquita. CRONE, Patricia. "Two legal problems bearing on the Early History of the Qur'an”, in: Jerusalem Studies in Arabic and Islam, 18, 1994, pp. 1-37.

${ }^{15}$ Outros exemplos consideram a clientela das crianças nascidas de uma mulher livre com um escravo posteriormente emancipado; e o escravo que é libertado do seu senhor (sảibah), neste caso, os vínculos são transferidos a toda comunidade muçulmana. Ver CRONE, op. cit., p. 68, sobre uma interessante interpretação dessa prática.

${ }^{16}$ No caso de se permitir ao escravo libertar um escravo de sua propriedade, os vínculos de clientela acumulados passam para o senhor original. BROCKOPP, op. cit., p. 153.

${ }^{17}$ Especificamente não pode ser comprada, vendida, ou objeto de desistência. Abd alHakam estendeu essas assertivas estabelecendo que esse vínculo não podia ser mudado pelas autoridades por danos físicos ao escravo. Idem, p. 153.

${ }^{18}$ Ibidem, p. 138.

${ }^{19}$ HUNWICK, John \& HARRAK, Fatima. Miraj Al-Su'ud: Ahmad Baba's replies on slavery. Rabat: Institute of African Studies, University Mohammed V Souissi, 2000, p. 7.

${ }^{20}$ Idem, p. 7. Ele utilizou o titulo alternativo al-Kashfwa'-bayan li-asnafmajlub al-sudan.

${ }^{21}$ Ibidem, p. 7.

${ }^{22}$ Sudan, plural de aswad, quer dizer "negro". Foi utilizado aqui em oposição ao termo bidan (branco), referente aos povos árabes e bérberes do Saara. 
${ }^{23}$ Termo aplicado coletivamente originalmente aos zoroastristas, do antigo Persa magush usado para designar os sacerdotes (magus, pl. magi), mais tarde usado genericamente a povos que não fossem judeus ou cristãos, mas com os quais os muçulmanos desejavam manter boas relações. Ver o hadith no qual o Profeta disse: "Trate-os como tratam o Povo do Livro" (judeus e cristãos). Ver: ANAS, Malik b. Muwatta al-imam Malik, riwayat Yahya al-Laythi. Beirut: Ratib Amrush, 1971, p. 188. No Mediterrâneo ocidental, entretanto, foi aplicado de forma hostil aos vikings.

${ }^{24} \mathrm{Idem}, \mathrm{p} .11$. O texto dessa fatwa faz parte do códice de al-Isis. O Sudão em questão é o bilad al-sudan, a "terras dos povos negros".

${ }^{25}$ KHALDUN, Ibn. The Muqaddimmah: An Introduction to History. Princeton: Princeton University Press, 1989, pp. 58-59.

${ }^{26}$ Abu Ishak Ibrahim b. Hilal al-Sijilmasi, (morto circa 1497-1498), jurista norte-africano célebre por suas fatwas.

${ }_{27}$ Shihab al-Din Ahmad b. Idris al-Qarafi al-Sanhaji (morto em 1285), jurista maliquita de origem bérbere que viveu no Cairo e advogava o princípio de que as leis deviam mudar conforme as circunstâncias.

${ }^{28}$ HUNWICK \& HARRAK, op. cit., p. 9.

${ }^{29}$ Idem, pp. 21-53.

${ }^{30}$ WILLIS, John R. Slaves and Slavery in Muslim Africa, vol.2: The Servile State. London: Frank Cass, 1985, p. 3.

${ }^{31}$ Idem, pp. 1-9.

${ }^{32}$ LOVEJOY, Paul E. “The Clapperton-Bello Exchange: the Sokoto Jihad and the TransAtlantic Slave Trade, 1804-1837," in Christopher Wise (ed.), The Desert Shore: Literatures of the African Sahel (Boulder: Lynne Rienner, 2000), p. 203.

33 SMITH, Abdallahi. "The Islamic Revolutions of the 19th Century”, in: Journal of Historical Society of Nigeria, 2, 1961, p. 176, MARTIN, B.G. Muslim Brotherhoods in the Nineteenth-Century Africa. Cambridge: Cambridge University Press, 1976, p. 18. Em 1817, no ano da morte de Uthman dan Fodio, seu irmão Abdullahi escreveu um tratado sobre os princípios do sufismo, que enfatizava a iniciação dele e Uthman dan Fodio, por intermédio de Jibril b. Umar. BRENNER, Louis. "Muslim thought in the Eighteenth-Century West Africa", in: LEVTZION, Nehemia \& VOLL, John O. Eighteenth-Century Renewal and Reform in Islam. Syracuse (NY): Syracuse University Press, 1987, pp. 56-57, Last, Murray. The Sokoto Caliphate. New York: Humanities Press, 1967, Murray Last, "Reform in West Africa: The Jihad Movements of the Nineteenth Century," in History of West Africa, ed. J. F. A. Ajayi and Michael Crowder (London, 1975). FARINHA, António Dias. "Os Marabutos e a Presença Portuguesa em Marrocos" in: Colectânea de Estudos em Honra do Prof. Doutor Damião Peres, Academia Portuguesa de Letras, Lisboa, 1974, pp.301-307.

${ }^{34}$ MARTIN, op. cit., p. 18.

${ }^{35}$ Idem, p. 18.

${ }^{36}$ Sabb al'-ajin 'alayha, freqüentemente mencionado por Uthman dan Fodio como signo de politeísmo. De forma análoga, Ibn al-Qadi enfatizava que sacrifícios a espíritos, árvo- 
res e outras criaçōes são formas de adoração. A única adoração possível é aquela dirigida exclusivamente a Deus. Seguindo os padrões estabelecidos por al Maghli, Ibn al-Qadi observou: "um muçulmano comete apostasia simplesmente por imitar um infiel” em práticas que somente um infiel realizaria. Pare ele, a shari'a trata apenas das manifestaçóes exótericas (zahir) do comportamento humano, e não de manifestações esotéricas (batin) que não podem ser vistas. MANSOUR, Mohamed Al \& HARRAK, Fatima. A Fulani jihadist in the Maghrib: Admonition of Ahmad Ibn al-Qadi at Timbukti to the Rulers of Tunisia and Morocco. Rabat: Institute of African Studies, 2000, p. 28.

${ }^{37} \mathrm{O}$ corolário para essa situação de acordo com a lei islâmica é que aquele que nasceu infiel (kafir bi l'asala) pode ser escravizado, enquanto os infiéis mencionados nas categorias 5 e 6 não devem ser escravizados se forem capturados como prisioneiros de guerra.

38 Pode-se incluir nessa categoria, a cobrança de taxas canonicamente ilegais, suborno, opressão e injustiça mencionados no Kitab al-farq, e as acusações de adoração de ídolos em Bornu.

${ }^{39}$ Essa categoria foi motivo de grande controvérsia entre os muçulmanos na época de dan Fodio. Os defensores do ilm al-kalam (erudição teológica) entre os talaba não aceitavam aqueles que não podiam explicar o significado dos artigos da fé. Uthman dan Fodio admoestou os talabas sobre essa atitude.

${ }^{40}$ MASRI, El F.H. (edited. and translated). Uthman ibn Fudi. Bayan wujub al-Hijra Ala 'L-'Ibad. Khartoum: Khartoum University Press, 1978, p. 8.

41 "A enfática negação ideológica do primado da identidade étnica (e posição social) que caracteriza as religiōes universais surgidas no Oriente Médio pode ser compreendida nesta perspectiva, já que praticamente qualquer movimento de reforma social ou ética nas sociedades poliétnicas dessa região colidiriam com as convenções e normas de caráter étnico." BARTH, Fredrik. O guru iniciador e outras variaçôes antropológicas. Rio de Janeiro: Contra Capa, 2000, p. 36.

42 Idem, pp. 36-37.

${ }^{43}$ São várias suratas e hadiths neste sentido. ZIDAN, Ahmad \& ZIDAN, Dina (text \& translation). Sahih Al-Bukhari. Cairo: Islamic INC, 1970, et passim. Em um hadith o Profeta enfatizou: "E árabe aquele que fala o árabe". No contexto, não deixa de ser uma tentativa de estender o conhecimento do idioma a qualquer povo que viesse estudar a revelação, independentemente de vínculos étnicos.

${ }^{44}$ BARTH, Fredrik. O guru iniciador e outras variaçôes antropológicas. Rio de Janeiro: Contra Capa, 2000, p. 72 e Nomads of South Persia: The Basseri tribe of the Khamseh Confederacy. Prospect Heights: Waveland Press, 1961.

${ }^{45}$ Idem, p. 73.

${ }^{46}$ MARTIN, op. cit., p. 126.

${ }^{47} \mathrm{O}$ trabalho de Martin enfocou vários movimentos islâmicos da África Ocidental, ao longo do Magrebe, até África Oriental. O xarifismo e a ação das irmandades sufis foram elementos importantes na mobilização das populações islâmicas e na legitimação de suas 
lideranças. Ver MARTIN, op. cit., et passim. Ver também o xarifismo marroquino e o conceito de imitatio Muhammadi, em CORNELL, Vincent. Realm of the Saints: Power and authority in Moroccan Sufism. Austin: University of Texas Press, 1998, pp. 129-229. ${ }^{48}$ EL MASRI, op. cit., p.9.

${ }^{49}$ LOVEJOY, The Bello-Clapperton Exchange, p. 204.

${ }^{50}$ HISKETT, M. The Sword of Truth. New York: Oxford University Press, 1973, p. 77.

${ }^{51}$ LOVEJOY, The Bello-Clapperton Exchange, p. 207.

52 Bello citou a fatwa de Ahmad Baba. Idem, p. 205. Sobre as comunidades fulas islamizadas e não-islamizadas ver: SILVA, Alberto da Costa e. Sobre a rebelião de 1835 na Bahia. Revista Brasileira, separata, FaseVII, abril-maio-junho 2002, Ano VIII, n 31, pp.13-14.

${ }^{53}$ LEVTZION, Nehemia. "Islam in African and Global Contexts: Comparative Studies of Islam", paper apresentado na conferência The Institute Of Global Studies, Binghampton University, April 19-22, 2001. Sobre a ascensão da comunidade xiíta no Líbano, ver: AJAMI, Fouad. The vanished Imam: Musa al-Sadr and the shia of Lebanon. Ithaca (NY): Cornell University Press, 1986. No caso libanês, exemplificado pela ascenção inconteste dos movimentos políticos-religiosos dos grupos xiitas Amal e Hezbollah.

${ }^{54}$ LOVEJOY, Paul E. "The Relation between Jihad and slavery in the Americas", apresentado no IFCS/UFRJ, Novembro de 2001.

55 ISHAQ, Ibn. The Life of Muhammad. London: Oxford University Press, 1955, p. 774.

${ }^{56}$ RYAN, Patrick J. Imale: Yoruba participation in the Muslim tradition. Missoula: Scholars Press, 1978, p. 1.

${ }^{57}$ HARROW, Kenneth, op.cit., in: LEVTZION \& POUWELS, op. cit., p. 519.

58 STARRAT, Priscilla. "Islamic influences on oral traditions in Hausa literature" in: HARROW, Kenneth. The marabout and the muse. Portsmouth (NH): Heinemann, 1996, p. 9.

${ }^{59}$ Idem, p. 164.

${ }^{60}$ Lewis, I.M. (ed.). Islam in tropical Africa. London: Oxford University Press, 1968 e DIOUF, Sylviane A. Servants of Allah: African Muslims enslaved in the Americas. New York: NYU Press, 1998, p. 4.

${ }^{61}$ OWASA-ANSAH, David. "Prayer, Amulets, and Healing”, in: LEVTZION \& POUWELS, op.cit., p. 480.

${ }^{62}$ A primeira e única tradução conhecida dos manuscritos feita na época da insurreição (1835) foi realizada pelo hauçá Albino na presença de um juiz de paz. MONTEIL, Vincent. "Anályse de 25 documents árabes dês Malés de Bahia (1835)", in: Bulletin de l'Institute Foundamentale d'Afrique Noire, ser.B, 29, números 1-2, 1967, pp.88-98 e REICHERT, Rolf. Os documentos árabes do Arquivo do Estado da Bahia. Centro de Estudos Afro-Orientais, Universidade Federal da Bahia, 1979.

${ }^{63}$ A tradução foi realizada pelo Nigerian Hinterland Project/UNESCO, York University, Toronto, Canadá. Agradeço ao Prof. Paul E. Lovejoy e especialmente a Ibrahim Hamza pela versão do árabe para o inglês. 
${ }^{64}$ DIOUF, op. cit., p. 107.

${ }^{65}$ AUSTIN, Allan D. African Muslims in antebellum America: Transatlantic stories and spirituals struggles. New York \& London: Routledge, 1997, p. 5.

${ }^{66}$ DWIGHT, Theodore. "Condition and character of negroes in Africa", in: SCHIEFFELIN, Henry. The people of Africa: A series of papers on their character, condition, and future prospects. New York: A.D.F. Randolph, 1871, p. 49.

${ }^{67}$ DIOUF, op. cit., p. 109.

${ }^{68}$ GOODY, Jack. The power of written tradition. Washington (DC): Smithsonian Institution Press, 2000, pp. 1-2.

${ }^{69}$ Idem, p. 106.

${ }^{70}$ LOVEJOY, Paul E. "The Muslim factor in the Atlantic Slave Trade”, Forthcoming in: LOVEJOY, Paul E. (ed.). African Slaves in Dar es-Salaam: The Central Sudan, Slavery, and the Muslim Diaspora. Princeton: Markus Wiener, p. 7.

${ }^{71}$ Idem, p. 7.

${ }^{72}$ Vamos considerar para efeitos conceituais a definição de Hunwick que alarga o conceito subjetivo de "erudito" ou "letrado", dessa forma o termo incluiria não apenas os institucionalmente reconhecidos como ulemás (cadis, jurisconsultos e professores), mas imans, khatibs, sufis ascetas, os místicos pietistas (sulahas), e em geral a todos inseridos na categoria de "homens-santos". Este termo englobaria um escopo considerável de categorias que correspondem, a entre outras, ao mandinga mori, ao fulfulde cerno, ao hauçá mallam, ao songai e iorubá alfa, ao arabo-sudanês faki, ao somali wadadi, ao ubíquo marabuto eremita ou santo) da terminologia franco-árabe. HUNWICK, John. "Secular Power and Religious Authority in Muslim Society: The Case of Songhay” in: Journal of African History, 37, 1996, pp. 175-194. O termo "marabuto" e derivado de murabit, que significa "eremita ou "santo". Possivelmente através da história islâmica ligado a ribat (centro religioso fortificado, português "rebate") ou a "rabita", "convento", português "arrábida". FARINHA, op. cit., p. 302 e FARIAS, Paulo de Fernando de Morais. "The Almoravids: Some questions concerning the character of the movement during its periods of closest contact with the Western Sudan" in: Bulletin de I.F.A.N. t. xxix, série B, 3-4, 1967, pp. 794-878, FARINHA, António Dias. "Contribuição para o estudo das palavras portuguesas derivadas do árabe-hispânico" in: Portugaliae Histórica, vol. 1, Lisboa, 1973, p. 262, no. 115. Em 1600 surge em espanhol a palavra morabito e em francês que conheceu grande difusão existe uma citação para 1651. CORAMINAS, Joan. Breve Diccionario etimológico de la lengua Castellana. Madrid: 1967, p. 402.

${ }^{73}$ DIOUF, op. cit., p. 39.

${ }^{74}$ REICHMUTH, Stefan. "Islamic Education and Schorlarship in Sub-Saharan Africa", in: LEVTZION \& POUWELS, op. cit., p. 419.

${ }^{75}$ Idem, p. 419.

${ }^{76}$ Ibidem, p. 421. De acordo com Gbadamosi, a interface do Islã com a cultura iorubá facilitou a introdução do primeiro na Iorubalândia. GBADAMOSI, T.G.O. The Growth 
of Islam among the Yoruba, 1841-1908. Atlantic Highlands (NJ): Humanities Press, 1978, p. 2.

77 “Devassa Do Levante De Escravos Ocorrido Em Salvador Em 1835” in: Anais do Arquivo Público do Estado da Bahia vol. 38, p. 130. Daqui em diante apenas "Devassa do Levante".

${ }^{78}$ RODRIGUES, Nina. Os africanos no Brasil. São Paulo: Companhia Editora Nacional, 1977.

${ }^{79}$ GOODY, op. cit., p.94.

${ }^{80}$ REIS, João José. Rebelião Escrava no Brasil: a história do levante dos malês. (Segunda Edição Revista e Ampliada.) São Paulo: Companhia das Letras, 2002 (no prelo).

${ }^{81}$ Segundo Ryan, na sua tese, o termo se refere à escola corânica. De forma mais acurada, resume melhor a instituição conhecida como "casa da recitação" porque envolve o aprendizado. RYAN, op. cit., p. 194.

82 "Quando esteve em Socoto em 1826, a capital do califado fula-hauçá, Clapperton observou algo semelhante numa escola corânica freqüentada por crianças das "classes média e baixa”. Os alunos recitavam em coro suas liçôes, escritas pelo mestre sobre as tábuas, que eram lavadas e a água bebida somente após terem eles decorado a lição. O gesto propiciatório estava então vinculado à memorização das oraçōes ou de passagens do Alcorão, uma espécie de recompensa pela tarefa cumprida. Assim se entende melhor as "vinte vezes escrita" do depoimento de Albino. Este, porém, pareceu distinguir entre exercícios elementares, sem eficiência protetora, e oraçóes mais complexas, estas sim bebidas para fechar o corpo. O uso tanto doméstico como militar dessa beberagem foi documentado em outro trecho do diário de Clapperton, escrito em Boussa, uma cidade do reino de Borgu, ao norte de Oió."

REIS, op. cit. Na Ilha de Bissau, o Aluhá é tábua onde escrevem-se os exercícios para os alunos. O aparo (Kalamo, literalmente "aparo", derivado do árabe Khalâm) é feito de delgadas hastes de bambu. A tinta obtém-se ou pela maceração de cascas (do tronco) da mangueira (árvore) ou de carvão vegetal reduzido a pó e misturado na água. CARREIRA, António. "Aspectos históricos da evolução do Islamismo na Guiné Portuguesa" in: Boletim Cultural da Guiné Portuguesa, Volume XXI, 84, 1966, pp. 455-457.

${ }^{83}$ DANMOLE, H.O. "Crises, Warfare, and Diplomacy in the Nineteenth-Century Ilorin”, in: FALOLA, Toyin. Warfare and diplomacy in precolonial Nigeria. African Studies Program (University of Winsconsin-Madison), 1992, p. 52 See J.F.A. AJAYI, J.F A. "The Aftermath of the Fall of Oyo", in AJAYI, J.F.A. \& CROWDER, M. History of West Africa II. London: Longman Publishing Group, 1987, pp. 129-166.

${ }^{84}$ Ondè é um amuleto costurado em uma bolsa de couro colocada em volta da cintura. Yfunpà é um amuleto de couro usado no braço. A pele de qualquer felino podia ser usada na confecção desses amuletos por causa da habilidade desses animais de se moverem furtivamente. No depoimento do forro nagô-igbo Lobão em 1835, ele descreveu os amuletos encontrados pela polícia em sua casa: "Foi perguntado qual era o fim para o que ele trazia aquilo, cujos patuás, ou embrulhos de couro foram abertos neste ato descosendo-se com 
um canivete de aparar penas, onde se achou vários fragmentos de cousas insignificantes, como seja algodão, embrulhado em um pouco de pó e outros até com bocadinhos de lixo e o saquinho com uns poucos de búzios dentro, envolto em um dos embrulhos de couro um pequeno papel escriturado com letras arábicas, ao que ele respondente, declarou, que trazia aquilo para o livrar do vento, e que os búzios servia-se deles para untar sabão na cabeça quando lavava." Devassa do Levante, vol. 53, p. 112. Leão, o africano na Granada muçulmana do final do século XV, descreveu os amuletos como sendo pequenas bolsas de couro contendo escritos misteriosos para proteção contra a inveja e doenças. "Os puristas consideravam essas práticas contrárias à religião. No entanto, seus próprios filhos freqüentemente usavam amuletos porque os primeiros não logravam fazer suas esposas e mães escutarem a razão. Eu não posso negar a utilização de amuletos por mim mesmo. Fui presenteado no meu primeiro aniversário com um desses artefatos com desenhos cabalísticos que nunca pude decifrar. Eu não acreditava no seu poder mágico, mas o homem é tão vulnerável ao Destino que não pode resistir à atração de objetos envoltos em mistério. Poderá Deus, que me criou tão fraco, um dia reprovar-me pela minha fraqueza?" MAALOUF, Amin. Leo Africanus. Lanham (MD): New Amsterdam books, 1988, p. 30. ${ }^{85}$ AJAYI, op. cit., in: AJAYI, J. F. A. \& CROWDER, M. op. cit., p. 46.

${ }^{86}$ Idem, pp. 129-166.

${ }^{87}$ Ver: SOUZA, Laura de Mello. O diabo e a terra de Santa Cruz: feitiçaria e religiosidade popular no Brasil colonial. São Paulo: Companhia das Letras, 1994, pp. 213-226.

88 "Relato do chefe de policia Francisco Gonçalves Martins". Jornal do Comércio, Rio de Janeiro, 10/02/1835.

${ }^{89}$ Ij6-170, jan-jul., 1835, Ofício do chefe de Polícia ao Ministro da Justiça, Arquivo Nacional. O documento foi publicado anteriormente em SOARES, Carlos Eugenio Líbano. A capoeira escrava e outras a tradiçôes rebeldes no Rio Janeiro (1808-1850). Campinas: Editora da Unicamp, 2001, p. 356. A presente transcrição foi feita diretamente da fonte. Agradeço a Alzira Durão pela transcrição.

${ }^{90} \mathrm{Na}$ América, certos rótulos étnicos implicavam em afiliação religiosa. Iorubá, por exemplo, podia incluir muçulmanos, apesar de freqüentemente se referir a não-muçulmanos (nagô e lucumi). O termo "iorubá” é aparentemente de origem hauçá e songhai cunhado do trabalho de Ahmad Baba em 1615 em Tombuctu no seu tratado de jurisprudência da escravidão no Islã. Nessa época, em Tombuctu, o songhai era falado e não o hauçá. O termo também foi usado em dendi, um dialeto do songhai falado em Borgu pelos comerciantes. No hauçá o termo é yarabawa (plural) e bayarabe (singular). LOVEJOY, Paul E. "The relationship between jihad and slavery in the Americas", p. 9. Ver também: LAW, Robin. "Ethnicity and the Slave Trade: "Lucumi" and Nago" as Ethnonyms in West Africa", in: History in Africa 24, 1997, pp. 205-219.

${ }^{91}$ LOVEJOY, “The Relationship between jihad and slavery in the Américas”, p. 11.

92 DIOUF, op. cit., pp. 11-13, 38, 135-137, 165-170.

${ }^{93}$ De acordo com Wilks, a tradição "quietista” a que ele se refere como a tradição suwariana envolvia "acomodação e coexistência", baseadas nas políticas e práticas estabelecidas por 
al-hajj Salim Suwari, inicialmente em Ja (Dia) em Massina e mais tarde em Jahaba, Bambuhu no final do século XV. Reverenciado por juula e jahanke, e desse modo associado de forma abrangente com os mandingos, al-hajj Salim Suwari advogava ser possível muçulmanos viverem em comunidades não-muçulmanas. Assim teriam acesso à riqueza por via do comércio e do artesanato nesse mundo, o que não significava a negação da salvação no "outro" mundo. Essa crença baseava-se na rejeição de um proselitismo ativo. A conversão real ocorreria apenas no reino de Deus. Portanto, o jihad era rejeitado como instrumento de mudança, exceto em situaçôes extremas de sobrevivência da comunidade muçulmana. Todos os infiéis seriam em algum momento convertidos, mas em estágios preestabelecidos. Aos muçulmanos restava manterem-se puros de acordo com a tradição do Profeta para esperar adequadamente a conversão futura dos infiéis. WILKS, Ivor. "Consul Dupuis and Wangara: A window on Islam in the early Nineteenth-Century Asante", in: Sudanic Africa, 6, 1995, p. 61.

${ }^{94}$ WILLIS, John R. In the Path of Allah: The passion of al-hajj Umar: An essay into the nature of charisma in Islam. London: Frank Cass \& Co., 1989, p. 49.

${ }^{95}$ MARTIN, op. cit., p. 29.

${ }^{96}$ Ver: Devassa Do Levante, vols. 38-40-50-54.

${ }^{97}$ Ver AUSTIN, op. cit.,

${ }^{98}$ LOVEJOY, "The relationship between jihad and slavery in the Americas", p. 12. Ver tambem: LOVEJOY, Paul E. and ADDAOUN, Yacine D. The Arabic Manuscript of Muhammad Kaba Saghanughu of Jamaica, c. 1823. University of West Indias, Mona, Jamaica, January 9-12, 2002, p. 10. O Kitab al-salat escrito por Muhammad Kaba na Jamaica, permitiu ligar os muçulmanos enviados para essa região como parte da tradição "quietista" da irmandade Qadiria no Sudão Ocidental, e revela a presença do sufismo no Caribe.

${ }^{99}$ COSTA, Emília Viotti da. Coroas de glória, lágrimas de sangue: a rebelião dos escravos de Demerara em 1823. São Paulo: Companhia das Letras, 1998, p. 232. No caso de Demerara, a participação maciça de escravos cristianizados, sob a liderança de um pastor inglês, pode ter influído decisivamente para o afastamento dos muçulmanos. Em contrapartida, podese constatar um caso de colaboração inter-religiosa na revolta de Denmark Vessey em Charleston, em 1822. ROBERTSON, David. Denmark Vessey. New York: Vintage Books, 2000, PEARSON, Edward A. Designs against Charleston: The Trial Record of the Denmark Vessey Slave Conspiracy of 1822. Chapel Hill: The University of Carolina Press, $1999 \mathrm{e}$ WALKER, Lois A. \& SILVERMAN, Susan. Documented History of Gullah Jack Pritchard and the Denmark Vesey Slave Insurrection of 1822. Lewiston: The Edwin Mellen Press, 2000. ${ }^{100}$ Coleção Instituto Histórico. "Livrinho Encontrado Preso ao Pescoço de um Negro Morto Durante a Insurreição dos Malês na Bahia”. Doação de J. de Sampaio Vianna, originais: IHGB, 102 p., lata 987, pasta 5.

${ }^{101} \mathrm{Na}$ África Ocidental, por exemplo, as famílias enviavam os filhos para a escola corânica quando a criança pudesse "contar ate dez". Os professores detinham total autoridade sobre os alunos, direito este outorgado pelo pai. Os estudantes começavam decorando a surah 
al-Fatiha (versículo de abertura do Corão) e as dez últimas suratas (conhecidas como "curtas”). O próximo estágio era estudar a gramática árabe, ler e recitar o texto corânico inteiro. Cada trecho $(a h z a b)$ decorado era celebrado. A cerimônia de formatura da instrução primária terminava com uma cerimônia em que o estudante ricamente vestido recitava a primeira parte do Corão diante dos professores, colegas e parentes. O professor era devidamente recompensado pelos pais com dinheiro e roupas novas. Esse aprendizado na escola corânica era também pré requisito básico para se iniciar a vida profissional. REICHMURT, op. cit., in: LEVTZION \& POUWELS, op. cit., p. 424. Leão, o africano, no início do século XVI, relatou sua experiência pessoal: "Para entender o significado da "grande recitação" na vida do crente é preciso ter vivido em Fes, cidade onde o aprendizado foi construído ao redor das escolas (madrasas). Apos vários anos de paciente memorização, chega-se a ponto de se recitar todos os versículos do Corão. Quando isso acontece, o professor declara o estudante pronto para a "grande recitação" e imediatamente passa da infância ao mundo dos homens, do anonimato para a fama. É quando alguns começam a trabalhar e outros são admitidos nos estágios superiores de aprendizado, fontes de erudição e autoridade". MAALOUF, op. cit., p.136. Sanim, um dos líderes da Revolta Malê, deixou escapar que apesar de todos os indícios apontarem-no como mestre, ele não exercia essa atividade em terras brasileiras: "Que é verdade ter o nome de Sanim na sua terra, mas que é falso o dizer se que ele ensina a língua, ou reza de Malê por que quando veio para terra de branco, não tratou mais disse, e nem se lembra”. Devassa do Levante, vol. 38, p. 119.

${ }^{102}$ Aquele reconhecidamente fraco, maltratado e oprimido. O mestre hauçá Dandará foi mais claro: "e que ele é Mestre em sua Terra, e que aqui ele tem ensinado os rapazes; porém que não é para mal. Devassa do Levante, vol. 54, p. 212.

${ }^{103}$ Livrinho Malê, p. 3. Surata An Nissá (As Mulheres, versículo 4: 102). A numeração obedecerá à paginação da tradução inglesa disponível em anexo na versão original da dissertação. A versão portuguesa usada no trabalho é a de Samir El Hayek. O Significado dos Versículos do Alcorão Sagrado, tradução Samir El Hayek. São Paulo: Marsam, 1994.

${ }^{104}$ Ver conceitos de qiya em: PHILIPS, Abu Ameenah Bilaal. Evolution of the Madh-habs (Schools of Islamic Law). Ryadh: International Islamic Publishing House, 1988/1409 AH. ${ }^{105} \mathrm{O}$ documento apresenta transcriçōes dos seguintes versículos: Al-Bácara (a Vaca), Áal 'Imran (A Família de Imran), Al-Nissá (As Mulheres), Al-Máida (A Mesa Servida), AlA'raf (Os Cimos), Yunis (Jonas), Hud (Hud), Ibrahim (Abraão), An Nahl (As Abelhas), Al-Cahf (A Caverna), Taha (Taha), Al-Anbiyá (Os Profetas), Al-Muminun (Os Crentes), Al-Furcan (O Discernimento), Ach Chu'ará (Os Poetas), Al-Cassas (As Narrativas), As Sajda (A Prostração), Al-Ahzáb (Os Partidos), Sabá (Sabá), Fáter (O Criador), Sad (A Letra Sad), Caf (A Letra Caf), Az Záriat (Os Ventos Disseminadores), Al-Camar (A Lua), AlMumtahana (A Examinada), Al Hácca (A Realidade), Al Máarij (As Vias de Ascensão), Al-Tahrim (As Proibições).

${ }^{106}$ RYAN, op.cit., p. 187.

107 Agradeço a Yacine Daddi Addaoun, doutorando do Nigerian Hinterland Project/ UNESCO, York University, seus comentários sobre o documento. 
${ }^{108}$ A vocalização breve no idioma árabe é feito com o uso de sinais diacríticos fatha, damma e kasra colocados sobre as consoantes. As vogais longas possuem letras específicas. SABBAGH, Alphonse N. Dicionário árabe-português-árabe. Rio de Janeiro: Ao Livro Técnico/Ed. UFRJ, 1988, p. 10.

${ }^{109} \mathrm{O}$ indivíduo que memoriza todo o texto corânico é chamado Huffaz.

${ }^{110}$ Havia dois africanos chamados Suleiman ou Sule envolvidos na rebeliāo de 1835 . Um era liberto nagô e foi o pivô da denúncia da rebelião devido à denúncia de sua companheira. O outro era escravo nagô do inglês Stuart e apontado como um dos mestres dos escravos muçulmanos da Vitória. Ambos teriam perecido em combate. Essa hipótese é reforçada pelo fato de o manuscrito ter sido encontrado no pescoço de um africano morto na revolta.

\section{Resumo}

$O$ artigo trata da origem da jurisprudência islâmica maliquita e na especificidade da sua aplicação à escravidão, além da evolução do debate em África envolvendo etnicidade, religião e escravização e de uma análise-sintese do manuscrito árabe que encontra-se no Instituto Histórico e Geográfico Brasileiro no Rio de Janeiro. Os tópicos abordados no artigo, originariamente, fazem parte de um contexto consideravelmente mais amplo, mas podem contribuir de forma positiva para alargar a discussão sobre o estudo da diáspora africana no Brasil.

\section{Abstract}

This article analizes the Malikite Islamic laws about slavery, the Muslim booklet held at Instituto Histórico e Geográfico Brasileiro no Rio de Janeiro, as well as the huge debate between Muslim scholars in Africa over questions of ethnicity, religion, and slavery. Though the scope has been narrowed for this article, the discussion nevertheless sheds new light on the African Diaspora in Brazil. 